\title{
Olfactory Receptor Patterning in a Higher Primate
}

\author{
Lisa F. Horowitz, ㄴuis R. Saraiva, Donghui Kuang, Kyoung-hye Yoon, and Linda B. Buck \\ Howard Hughes Medical Institute, Basic Sciences Division, Fred Hutchinson Cancer Research Center, Seattle, Washington 98109
}

The mammalian olfactory system detects a plethora of environmental chemicals that are perceived as odors or stimulate instinctive behaviors. Studies using odorant receptor (OR) genes have provided insight into the molecular and organizational strategies underlying olfaction in mice. One important unanswered question, however, is whether these strategies are conserved in primates. To explore this question, we examined the macaque, a higher primate phylogenetically close to humans. Here we report that the organization of sensory inputs in the macaque nose resembles that in mouse in some respects, but not others. As in mouse, neurons with different ORs are interspersed in the macaque nose, and there are spatial zones that differ in their complement of ORs and extend axons to different domains in the olfactory bulb of the brain. However, whereas the mouse has multiple discrete band-like zones, the macaque appears to have only two broad zones. It is unclear whether the organization of OR inputs in a rodent/primate common ancestor degenerated in primates or, alternatively became more sophisticated in rodents. The mouse nose has an additional small family of chemosensory receptors, called trace amine-associated receptors (TAARs), which may detect social cues. Here we find that TAARs are also expressed in the macaque nose, suggesting that TAARs may also play a role in human olfactory perception. We further find that one human TAAR responds to rotten fish, suggesting a possible role as a sentinel to discourage ingestion of food harboring pathogenic microorganisms.

Key words: macaque; odorant receptor; primate; trace-amine associated receptor

\section{Introduction}

The first step in odor perception is the binding of odorants to odorant receptors on olfactory sensory neurons (OSNs) in the nasal olfactory epithelium (OE) (Buck and Axel, 1991; Mombaerts, 2004; Munger et al., 2009; Buck and Bargmann, 2012). Odorant receptors (ORs) are encoded by a large multigene family that is evolutionarily conserved among vertebrates, but most extensively studied in mice. Mice have $\sim 1000$ different ORs, whereas humans have $\sim 350$ (Glusman et al., 2001; Zhang and Firestein, 2002; Godfrey et al., 2004; Malnic et al., 2004; Niimura and Nei, 2005).

The mouse (and rat) OE has a series of multiple, partially overlapping, spatial zones along its dorsal-ventral axis that express different OR genes and project axons to roughly corre-

\section{Received April 19, 2014; revised July 1, 2014; accepted July 22, 2014}

Author contributions: L.F.H., L.R.S., D.K., K.-h.Y., and L.B.B. designed research; L.F.H., L.R.S., D.K., and K.-h.Y. performed research; L.F.H., L.R.S., D.K., and K.-h.Y. analyzed data; L.F.H., L.R.S., and L.B.B. wrote the paper.

This work was supported by the Howard Hughes Medical Institute (L.B.B.) and by National Institutes of Health Grants F32 DC007562 (L.F.H.), F32 DC011699 (K.Y.), and R01 DC009324 (L.B.B.). We thank R. Robinson, C. Kaneko, S. Juul, and L. Sincich for tissue samples; J. Young and B. Trask for unpublished data on macaque OR genes; members of the Buck laboratory for helpful discussions and comments on the manuscript; K. Hudkins and the Alpers Pathology Service at the University of Washington for assistance and resources, and for performing some of the in situ hybridization experiments.

The authors declare no competing financial interests.

Correspondence should be addressed to Dr Linda Buck, Fred Hutchinson Cancer Research Center, 1100 Fairview Avenue North, A3-020, Seattle, WA 98109-1024. E-mail: Ibuck@fhcrc.org.

L. F. Horowitz's present address: Department of Bioengineering, University of Washington, Seattle, Washington, 98195.

L. R. Saraiva's present address: European Molecular Biology Laboratory-European Bioinformatics Institute and Wellcome Trust Sanger Institute, Wellcome Trust Genome Campus, Hinxton-Cambridge CB10 1SD, United Kingdom.

K.-h. Yoon's present address: School of Life Sciences, Ulsan National Institute of Science and Technology, Ulsan, 689-798, South Korea.

DOI:10.1523/JNEUROSCI.1779-14.2014

Copyright $\odot 2014$ the authors $\quad 0270-6474 / 14 / 3412241-12 \$ 15.00 / 0$ sponding domains in the olfactory bulb (OB) (Ressler et al., 1993; Vassar et al., 1993; Sullivan et al., 1996; Iwema et al., 2004; Miyamichi et al., 2005). Individual OSNs appear to express one allele of a single OR gene (Chess et al., 1994; Malnic et al., 1999). Those with the same OR are scattered within one OE zone, but their axons converge in a few glomeruli at semistereotyped locations in the OB (Ressler et al., 1994; Vassar et al., 1994; Mombaerts et al., 1996).

ORs are used in different combinations to detect different odorants, thereby allowing the discrimination of a multitude of odorants (Malnic et al., 1999; Kajiya et al., 2001). Nonetheless, the mouse $\mathrm{OE}$ has a second family of chemosensory receptors comprising 14 trace amine-associated receptors (TAARs; Liberles and Buck, 2006). Like ORs, TAARs are evolutionarily conserved from fish to humans (Gloriam et al., 2005). At least three mouse TAARs recognize volatile biogenic amines that cause behavioral attraction or aversion, suggesting that some TAARs detect social cues (Liberles and Buck, 2006; Ferrero et al., 2011; Dewan et al., 2013; Li et al., 2013; Zhang J. et al., 2013).

One important question that remains to be answered is whether the organization of olfactory receptor inputs and TAAR expression observed in mouse is recapitulated in primates, such as humans. To address this question, we turned to the macaque, a higher primate phylogenetically close to humans (Janecka et al., 2007). We found that fundamental aspects of OR gene expression observed in mouse are conserved in macaque, as is a dorsalventral organization of the axonal projection to the OB. However, whereas mouse OR genes are typically each expressed in a spatial zone occupying approximately one-quarter of the OE, individual macaque OR genes are each expressed in a spatial zone that occupies approximately one-half the OE. 
We found that TAARs are also expressed in the macaque OE, suggesting that these receptors may also function as chemosensory receptors in the human nose. In vitro analyses revealed that one macaque TAAR and its human homolog both detect an amine repulsive to humans. The human homolog also responds to rotten fish, suggesting that this receptor may convey innately aversive signals in humans and thereby play a role in discouraging the ingestion of spoiled food.

\section{Materials and Methods}

Tissue preparation. Macaque olfactory tissue was generously donated by several groups studying other aspects of macaque biology. Paraformaldehyde-perfused tissue from adult male Macaca mulatta was obtained from C. Kaneko and R. Robinson, University of Washington (Animals 6, 10, 11, and 13; 3\% PFA), and from L. Sincich and J. Horton, University of California at San Francisco (Animal 9; 1\% PFA, postfixed in $4 \%$ PFA). Juvenile $M$. nemestrina ( 9 months of age, 1 male and 1 female; $4 \%$ PFA) were obtained from S. Juul, University of Washington (Animals 8 and 12). A tissue block containing the dorsal posterior nasal cavity was isolated (except for Animals 6 and 9 for which the septum and middle turbinate were each isolated for analysis). Nasal tissue was postfixed and decalcified for 1-2 weeks in 2\% PFA in PBS and 0.25 M EDTA and then cut in the coronal plane into $\sim 0.5 \mathrm{~cm}$ anterior-posterior segments. The segments were embedded in paraffin or OCT (Miles), and then used to prepare $8 \mu \mathrm{m}$ paraffin sections (Animals $4,6,8,9$, and 11) or $14 \mu \mathrm{m}$ frozen sections (Animals 10 and 13). OBs (Animals 8, 10, 13) were postfixed for $2 \mathrm{~h}$ in $4 \%$ PFA/PBS, cryoprotected in 30\% sucrose, and embedded in OCT. Frozen sections $(14 \mu \mathrm{m})$ were taken in the coronal plane.

In situ hybridization. Radioactive in situ hybridization was performed with paraffin or frozen sections using ${ }^{33} \mathrm{P}$-labeled antisense (or control sense) cRNA probes and developed after 2 weeks, as described previously (Ressler et al., 1993). Full coding regions of olfactory marker protein (OMP), OR, and TAAR genes were cloned from M. mulatta genomic DNA (Biochain) and used to prepare probes. A full set of M. mulatta OR gene sequences from the January 2006 genome draft was kindly provided by J. Young (Fred Hutchinson Cancer Research Center, unpublished data). For the OCAM (olfactory cell adhesion molecule, NCAM2) probe, a segment containing nucleotides 395-1302 was cloned from cDNA prepared from M. mulatta brain RNA (Biochain) using Superscript III (Invitrogen). Control experiments using sense-strand probes for TAAR2, TAAR5, and OR52K2L showed no significant signal in the OE. We sometimes saw dispersed signal from the OR52K2L antisense probe scattered below the surface of the $\mathrm{OE}$ in the lamina propria, but no signal was seen with the OR52K2L sense probe. We estimated the number of crosshybridizing genes using BLASTN (NCBI) of intact $M$. Mulatta OR genes with a cutoff of at least $400 \mathrm{nt}$ with at least $80 \%$ identity. Some of the in situ hybridization experiments were performed by the Alpers Laboratory Pathology Service at the University of Washington. Despite numbers of OR-positive cells similar to the other animals, almost no TAAR-positive cells were seen in Animal 9 (the only animal perfused with a very low concentration of fixative) and the animal was not included in the TAAR analysis.

Immunohistochemistry. Antibody staining was performed using the $\mathrm{ABC} / \mathrm{DAB}$ system (Vector Laboratories). Tissue sections were pretreated with $0.6 \% \mathrm{H}_{2} \mathrm{O}_{2}$, washed with TNT $(0.1 \mathrm{M}$ Tris $\mathrm{pH} 7.5,150 \mathrm{~mm} \mathrm{NaCl}$, $0.05 \%$ Tween), and blocked in TNB (TSA kit, PerkinElmer) with $0.1 \%$ Triton X-100. Sections were incubated with primary antibody diluted in blocking solution overnight at $4^{\circ} \mathrm{C}$ : goat anti-OMP $(1 / 1800$, Wako) or Goat anti-NCAM2/OCAM (R\&D Systems, 1/600-1/1000). They were then incubated with secondary antibody for $1 \mathrm{~h}$ (biotinylated rabbit antigoat, Vector Laboratories, $0.8 \mu \mathrm{g} / \mathrm{ml}$, in blocking solution) followed by 30 min with $\mathrm{ABC}$ reagent, and then developed with the $\mathrm{DAB}$ reagent (Vector Laboratories).

Image analysis. In situ hybridization experiments with $\mathrm{OR}$ and TAAR probes were analyzed as follows. Montage images of hybridized sections were taken at $1.25 \times$ (panorama feature, Zeiss Axiophot) or at $5 \times$ on a Zeiss M1 microscope using TissueFAXS (TissueGnostics). Positive signal over olfactory sensory neurons was confirmed at $10 \times$ or higher- magnification. Locations of positive cells were marked onto images using Adobe Photoshop and Adobe Illustrator. The location of OE was determined by positive OMP signal. Distances along the OE were measured on OCAM and OMP sections using segmented line lengths (ImageJ). Outlines with $\mathrm{OCAM}^{+}$AND OCAM ${ }^{-}$regions and tissue borders taken from nearby sections were superimposed on the images to determine the locations of cells with respect to OCAM. Sometimes the locations of cell dots do not directly correspond to the OCAM outline as the outline is from a nearby section. Cells in OE that extended further than the OCAM outline were not counted though they are present on the outline/dot figures. Relative cell density for $\mathrm{OCAM}^{-}$and $\mathrm{OCAM}^{+}$regions (given as percentage) was calculated for each animal as the cell density in one region divided by the sum of the densities in both regions. Overcounting correction was applied to the cell densities as follows. Using Abercrombie's formula $[T /(T+h) ; T=$ section thickness, $h=$ mean object diameter in the $z$-axis], we calculated the adjustment to be $\sim 0.66$ (cell diameter $7.3 \mu \mathrm{m}$ ) for $14 \mu \mathrm{m}$ cryosections, and 0.54 (cell diameter 6.7 $\mu \mathrm{m}$ ) for $8 \mu \mathrm{m}$ sections. Average cell diameter was estimated from OMP antibody stained OSNs for cryosections and nonradioactive OMP antibody in situ hybridization of paraffin sections (performed as in Liberles and Buck (2006) except substituting streptavidin fluorophore for development with $\mathrm{ABC}$ and $\mathrm{DAB})$. Average OSN density was estimated by counting the numbers of OMP-immunostained cells per $100 \mu \mathrm{m}$ regions, taken from 27 regions distributed around all OMP-positive areas in cryosections of two areas from Animal 13. A rough estimate of the surface area of the OE was obtained as follows. The linear length of $\mathrm{OMP}^{+} \mathrm{OE}$ was measured with Image for three animals with three $\mathrm{OMP}^{+}$sections, each $\sim 0.5 \mathrm{~cm}$ apart. Given the large gaps between sections for any one animal, known anatomy was used to combine these sections to make one model animal. The total surface area was estimated by the area under the curve of the best fit for the distances.

Given the restricted number of OR probes in this study, we calculated the possibility that we may be missing mouse-like OR patterns in the macaque using a hypergeometric distribution. In mouse, there is a 0.014 probability to find that 80 of 80 ORs tested (of 1035 total) have a mouselike pattern (Miyamichi et al., 2005), if 5\% or more of ORs were to have a different pattern. Therefore, at least $95 \%$ of all mouse ORs are likely to have a mouse-like pattern. We find that 0 of 6 macaque ORs tested (of 309 ORs total) had a mouse-like pattern. The probability of this result is $0.046,0.002$, or $7.0 \times 10^{-9}$, if the percentage of all macaque ORs with a mouse-like pattern were $40 \%, 75 \%$, or $95 \%$ respectively. Thus, it is very unlikely that $40 \%$ of the macaque ORs have a mouse-like pattern, even less likely that it is a majority, and extremely unlikely that macaque and mouse are the same.

TAAR functional analysis. Secreted alkaline phosphatase (SEAP) assays were performed in 96-well plates as previously described (Liberles and Buck, 2006). In brief, HEK 293 cells (ATCC) were transfected with plasmids encoding all intact mouse, macaque, or human TAAR genes (except for TAAR1) with or without a 20 aa $\mathrm{N}$-terminal bovine rhodopsin tag (rho tag). Cells (100,000 per well) were cotransfected with $20 \mathrm{ng}$ receptor plasmid and a CRE-SEAP reporter plasmid (BD Biosciences) using Lipofectamine Plus or Lipofectamine 2000 (Invitrogen). After overnight incubation, cells were incubated with ligand. After $24 \mathrm{~h}$, an aliquot was then incubated with an equal volume of $1.2 \mathrm{~mm}$ 4-methylumbelliferyl phosphate (Sigma-Aldrich) in $2 \mathrm{~m}$ diethanolamine bicarbonate and fluorescence was measured with a CytoFluor 4000 plate reader (Applied Biosystems). Amines tested are listed below. Putative ligands positive in the primary screen ( 2 wells/ligand) were then tested with dose-response curves in a secondary screen. Spoiled food samples were prepared by putting $3 \mathrm{~g}$ of minced food into $50 \mathrm{ml}$ of PBS and leaving at room temperature for $10 \mathrm{~d}$ (fresh food was immediately processed). After vortexing, the samples were cleared by centrifugation and filter sterilized with a $0.22 \mu \mathrm{m}$ filter. Significant responses were seen for TAAR5 to two separate preparations of salmon, but results are shown for one preparation. Experiments shown in Figure 4 were done using TAARs with a rho tag, but experiments using TAARs without a rho tag showed similar results.

Amines tested. The following amines were tested: carnitine, 3-methylpropylamine, octopamine, benzylamine, spermidine, spermine, agmatine, 
A

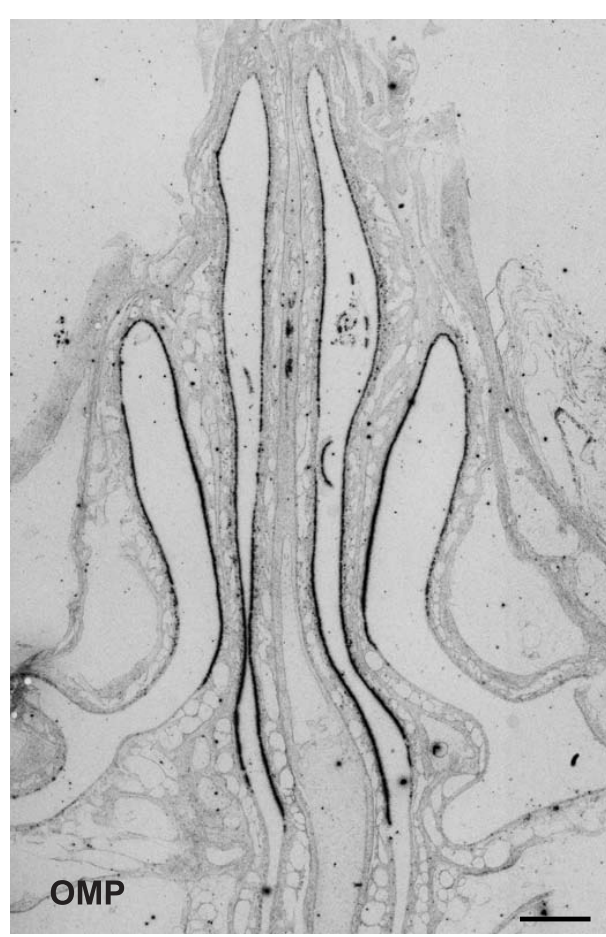

B

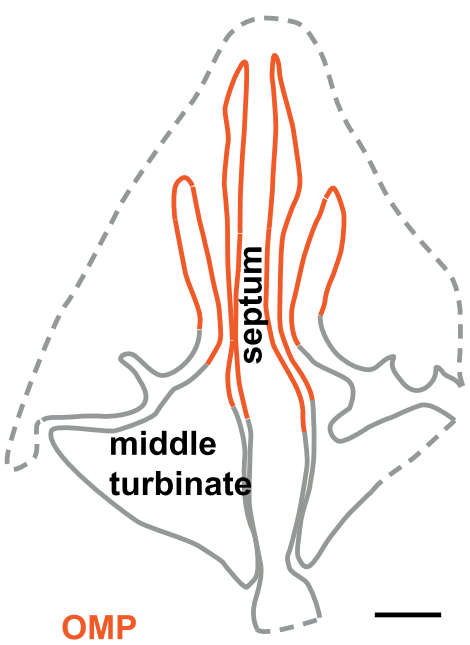

C

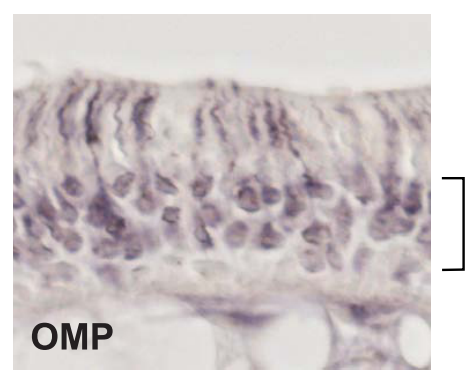

D

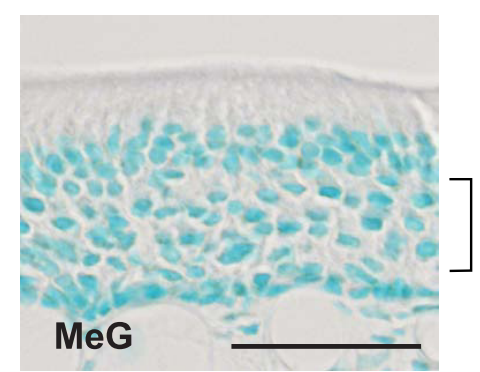

Figure 1. Configuration of the macaque olfactory epithelium. In a coronal section through the macaque nasal cavity, a ${ }^{33} \mathrm{P}$ labeled OMP CRNA probe hybridized to OSNs in OE present on dorsal parts of the nasal septum, medial turbinates, and lateral wall $(\boldsymbol{A})$, as shown in orange in a schematic diagram $(\boldsymbol{B})$. OSNs immunostained for OMP were located in a central region of the $0 \mathrm{E}$, but not in more apical and basal cells that were also stained by methyl green (MeG; $\boldsymbol{C}, \boldsymbol{D})$. Scale bars: $\boldsymbol{A}, 1 \mathrm{~mm} ; \boldsymbol{B}, 2 \mathrm{~mm} ; \boldsymbol{C}, \boldsymbol{D}, 0.1 \mathrm{~mm}$.

ethylenediamine, butylamine, propylamine, ethyleneamine, isobutylamine, triethanolamine, putrescine, tyramine, cyclohexylamine, isobutylamine, pyrrolidine, cystamine, cadaverine, methylamine, tryptamine, $N, N$-methyl-beta-phenethylamine, isoamylamine, 2-methyl-butylamine, benzenamine, epinephrine, serotonin, 1-piperidine ethanol, 1-(2-aminoethyl)piperidine, creatinine, tri-iodotyronine $\mathrm{t} 3$, acetominophen, L-thyroxine $\mathrm{t} 4$, trymethylamine (TMA), 2-betaphenylethylamine, L-citrulline, nicotinic acid, L-tryptophan, DL-metanephrine, androsterone, DL-normetanephrine, taurine, homovanillic acid, $N, N$ dimethylglycine, trimethylamine $N$-Oxide dihydrate, creatinine, $N, N$ dimethyl-L-phenilalanine, 5-aminoindole $\mathrm{HCl}$, $\mathrm{N}$-propyl benzamide, capsaicin, synephrine, L-glutathione, 5-hydroxyindole-3-acetic acid, chloroamine, 3-hydroxy-DL-kynurenine, oxytocin, Lornithine, trigonelline, tyramine, 2-naphtylamine, carbamoylcholine chloride, $3^{\prime}$ - aminoacetophenone, $4^{\prime}$-aminoacetophenone, ethylene diamine, carnitine, indole, $N$-methyl-L-proline, $2^{\prime}$-aminoacetophenone, 4-(dimethylamine) butyric acid, 4-butylaniline, $N, N$-dimethyl cyclohexilamine, pyrrolidine, isoamylamine, $N$-methyl-piperidine, 3 -methylindole, 4-piperidone, $\mathrm{N}, \mathrm{N}$-dimethyldodecylamine, 2-piperidone, melatonin, uracil, L-kynurenine, kynurenic acid, 3-aminopyridine, 4-aminopyridine, 2-methylpyridine 2-picoline, 1-methylpiperazine, 2,5dimethylpiperazine, 2,3,5-trimethylpyrazine, 2-methyl-2-imidazoline, thiourea, $N, N$-dimethylthiourea, 6-amino-nicotinic acid, $N, N$-dimeth- yl-1-tetradecylamine, urea, 1,2,3,4-tetrahydroquinoline, 2-ethyl-3,5(or 6)-dimethylpyrazine, methylurea, 4-piperidine methanamine, L-pipecolic acid, 1-ethylpiperidine, 1-(2-Aminoethyl)piperidine, 1-piperidinepropanol, 1-(2hydroxyethyl)pyrrolidine, 1-(2-aminoethyl) pyrrolidine, L-prolinol, $N$,methyl-pyrrolidine, isopropylamine, p-aminobenzoic acid, ethanolamine, GABA, adenine, beta-alanine, trimethylamine oxide, 2-methyl-butanol, cyclohexanol, $\mathrm{N}$-benzylmethylamine, $\mathrm{N}$-methylaniline, 3-(methylthio)-propylamine, aniline, 2-methoxipyrazine, pyridine, alpha-methylbenzylamine, $N$, $N$,dimethylethilene diamine, 3-phenyl-1propylamine, diethanolamine, 2-methyl-pyrazine, 1-methylpyrrole, isoquinoline, diphenylamine, 2-acetylpyridine, piperazine, pentylamine, pyrazine, 1,1-dimethylurea, 2-amino-4-picoline, triethylenetetramine, $N^{\prime}$-benzyl- $N, N$-dimethylethylene diamine, $N, N, N^{\prime}, N^{\prime}$-tetraethyl diethylenetriamine, $N, N^{\prime}$-dibenzylethylenediamine, 1 -methyl-3 phenyl-propylamine, $N, N, N^{\prime}$, $N^{\prime}$-tetramethyl-1,3-butanediamine, 2,3-dimethylpyrazine, 2,6-dimethylpyrazine, 3,4-dimethoxyphenethylamine, choline chloride, bornylamine, cysteamine hydrocloride, dimethylbenzylamine, dimethylamine, trimethylamine- $N$-oxide, 3-picoline, 4-picoline, 2-ethylpiperidine, 3-methylpyrrole, 4-hydroxybenzylamine, 1,5-dimethyl-1- $H$-pyrrozole, 3-dimethylamino-1-propanol, $N$, $\mathrm{N}$-dimethylbutylamine, 1-napthylamine, 1 -methylindole, $N, N$-dimethyl-1-napthylamine, $N, N, N^{\prime}, N^{\prime}$-tetramethyl-1,4-butanediamine, 2,5-dimethylpyrazine, triethylamine, $N, N$-dimethyloctylamine, pyrridine- $N$-oxide, $\mathrm{N}, \mathrm{N}$-dimethylethanolamine, $\mathrm{N}, \mathrm{N}$-dimethylethylamine, $N$-benzylethilenediamine, $N(1)$-octyl-1,2-ethanediamine, dansylcadaverine, 3-hydroxy-4-methoxiphenethylamine, 3-methoxy-tyramine hydrochloride, melatonin, 5-hydroxy-indole, 2-dimethylamino-6-hydroxipurine.

\section{Results}

\section{Dispersed expression of OR genes in the} macaque nose

To investigate OR and TAAR expression in the OE of a higher primate, we analyzed 5 adult rhesus macaques ( $M$. mulatta). We also examined two juvenile macaques of a different species $(M$. nemestrina). Similar to humans, the rhesus macaque has $\sim 300$ intact OR genes and 6 intact TAAR genes (Niimura and Nei, 2007).

To assess the distribution of the macaque OE and its complement of OSNs, we first examined OMP, a protein expressed by rodent, as well as macaque, OSNs (Margolis, 1982; Smith et al., 1991). In these and subsequent experiments, we analyzed coronal sections taken at intervals along the anterior-posterior axis of the nasal cavity. Hybridization with an OMP cRNA probe showed that the OE covers parts of the posterior nasal septum, the dorsal and lateral walls of the nasal cavity, and the middle turbinate, which protrudes into the nasal lumen from the posterior wall (Fig. $1 A, B$ ). The OE extended for $\sim 20 \mathrm{~mm}$ in the anterior-posterior dimension and a maximum of $\sim 11 \mathrm{~mm}$ in the dorsalventral dimension.

The long length of the OE precluded analysis throughout its full extent, but measurements at several locations suggested that 
Table 1. OR gene expression in macaque $0 \mathrm{E}$

\begin{tabular}{|c|c|c|c|c|c|c|c|}
\hline$\overline{\text { OR gene (No. of genes) }}{ }^{a}$ & Animal $^{b}$ & No. of OCAM ${ }^{-}$cells & OCAM $^{-}$density $^{c}$ & No. of $\mathrm{OCAM}^{+}$cells & $\mathrm{OCAM}^{+}$density $^{\mathrm{c}}$ & OCAM $^{-}(\%)$ & Fraction of OSNs \\
\hline \multirow[t]{8}{*}{ OR52K2L (2) } & 6 & 110 & 172 & 0 & 0 & 100 & \\
\hline & 9 & 127 & 66 & 1 & 0.6 & 99 & \\
\hline & 10 & 1082 & 435 & 9 & 5.9 & 99 & \\
\hline & 11 & 340 & 141 & 27 & 26 & 84 & \\
\hline & 13 & 386 & 342 & 14 & 6 & 98 & \\
\hline & Avg & & $246 \pm 67$ & & $7.7 \pm 4.7$ & $96 \pm 3$ & $1 / 306$ \\
\hline & 8 & 389 & 272 & 11 & 30 & 90 & \\
\hline & 12 & 185 & 115 & 2 & 5.1 & 96 & \\
\hline \multirow[t]{8}{*}{ OR8B8 (4) } & 6 & 416 & 407 & 10 & 51 & 89 & \\
\hline & 9 & 169 & 299 & 12 & 27 & 92 & \\
\hline & 10 & 2262 & 909 & 238 & 155 & 85 & \\
\hline & 11 & 1245 & 341 & 20 & 13 & 96 & \\
\hline & 13 & 531 & 470 & 152 & 66 & 88 & \\
\hline & Avg & & $484 \pm 11$ & & $63 \pm 25$ & $90 \pm 2$ & $1 / 267$ \\
\hline & 8 & 54 & 75 & 4 & 22 & 77 & \\
\hline & 12 & 377 & 185 & 7 & 18 & 91 & \\
\hline \multirow[t]{8}{*}{ OR8A1L2 (2) } & 6 & 308 & 301 & 4 & 21 & 94 & \\
\hline & 9 & 217 & 385 & 58 & 129 & 75 & \\
\hline & 10 & 1170 & 470 & 186 & 121 & 80 & \\
\hline & 11 & 537 & 159 & 21 & 15 & 91 & \\
\hline & 13 & 417 & 369 & 85 & 34 & 92 & \\
\hline & Avg & & $339 \pm 50$ & & $65 \pm 25$ & $86 \pm 4$ & 1/183 \\
\hline & 8 & 149 & 104 & 5 & 14 & 88 & \\
\hline & 12 & 402 & 197 & 9 & 23 & 90 & \\
\hline \multirow[t]{8}{*}{ OR4X2L (1) } & 6 & 13 & 5.4 & 12 & 27 & 17 & \\
\hline & 9 & 4 & 7.1 & 41 & 91 & 7 & \\
\hline & 10 & 6 & 2.4 & 55 & 36 & 6 & \\
\hline & 11 & 56 & 9.3 & 88 & 23 & 29 & \\
\hline & 13 & 2 & 1.8 & 120 & 48 & 4 & \\
\hline & Avg & & $5.2 \pm 1.5$ & & $43 \pm 13$ & $13 \pm 5$ & $1 / 754$ \\
\hline & 8 & 122 & 45 & 45 & 57 & 45 & \\
\hline & 12 & 0 & 0 & 0 & 0 & & \\
\hline \multirow[t]{8}{*}{ OR2Y1 (1) } & 6 & 206 & 219 & 13 & 43 & 84 & \\
\hline & 9 & 116 & 206 & 36 & 80 & 72 & \\
\hline & 10 & 1007 & 405 & 177 & 115 & 78 & \\
\hline & 11 & 521 & 236 & 79 & 57 & 80 & \\
\hline & 13 & 174 & 160 & 169 & 71 & 69 & \\
\hline & Avg & & $233 \pm 46$ & & $74 \pm 12$ & $77 \pm 3$ & 1/115 \\
\hline & 8 & 54 & 75 & 10 & 55 & 58 & \\
\hline & 12 & 4 & 2.8 & 0 & 0 & & \\
\hline \multirow[t]{8}{*}{ ORAE2 (1) } & 6 & 17 & 8.8 & 67 & 97 & 8 & \\
\hline & 9 & 48 & 33 & 67 & 50 & 40 & \\
\hline & 10 & 16 & 6.4 & 135 & 98 & 6 & \\
\hline & 11 & 73 & 18 & 416 & 200 & 8 & \\
\hline & 13 & 2 & 1.8 & 285 & 114 & 2 & \\
\hline & Avg & & $8.7 \pm 3.0$ & & $105 \pm 18$ & $13 \pm 7$ & $1 / 301$ \\
\hline & 8 & 24 & 15 & 14 & 25 & 38 & \\
\hline & 12 & 3 & 1.5 & 4 & 10 & & \\
\hline
\end{tabular}

In situ hybridization data are shown for $0 R$ probes matching six $M$. mulatta $O R$ genes.

${ }^{a}$ Number of genes predicted to hybridize to each probe given sequence relationships.

${ }^{b}$ M. mulatta: Animals 6, 9, 10, 11, and 13; M. nemestrina: Animals 8 and 12.

'Density of hybridized neurons in 0 E after overcounting correction and given as labeled cells $/ \mathrm{mm}^{2} \mathrm{OE}$ surface area, Avg \pm SEM. Total density assuming $51 \% 0$ CAM + (see Materials and Methods). $0 \mathrm{R} /$ animal combinations with $<20$ cells are not included. Fraction of OSNs is adjusted for predicted number of genes that should hybridize to each probe and thus indicates the fraction of 0 SNs per gene recognized by the probe. The estimated total OSN cell density is 18,590 cells $/ \mathrm{mm}^{2}$ (see Materials and Methods).

the $\mathrm{OE}$ has a surface area of $\sim 800 \mathrm{~mm}^{2}$ in M. mulatta. The density of neurons immunostained for OMP (Fig. 1C,D) averaged $18,590 \pm 950$ cells $/ \mathrm{mm}^{2} \mathrm{OE}$ surface area, suggesting that the animal has $\sim 15$ million OSNs, compared with $\sim 5-8$ million in mouse (Pomeroy et al., 1990; Mackay-Sim and Kittel, 1991; Ressler et al., 1993).
We next analyzed the expression of OR genes. Using BLASTN to search a compilation of intact $M$. mulatta OR genes, we selected six macaque OR genes that are close homologs (80-86\% nucleotide sequence identity) of mouse OR genes expressed in various OE zones: OR52K2L, OR8B8, OR8A1L2, OR4X2L, OR2Y1, and OR4E2. The mouse homologs of the first three 


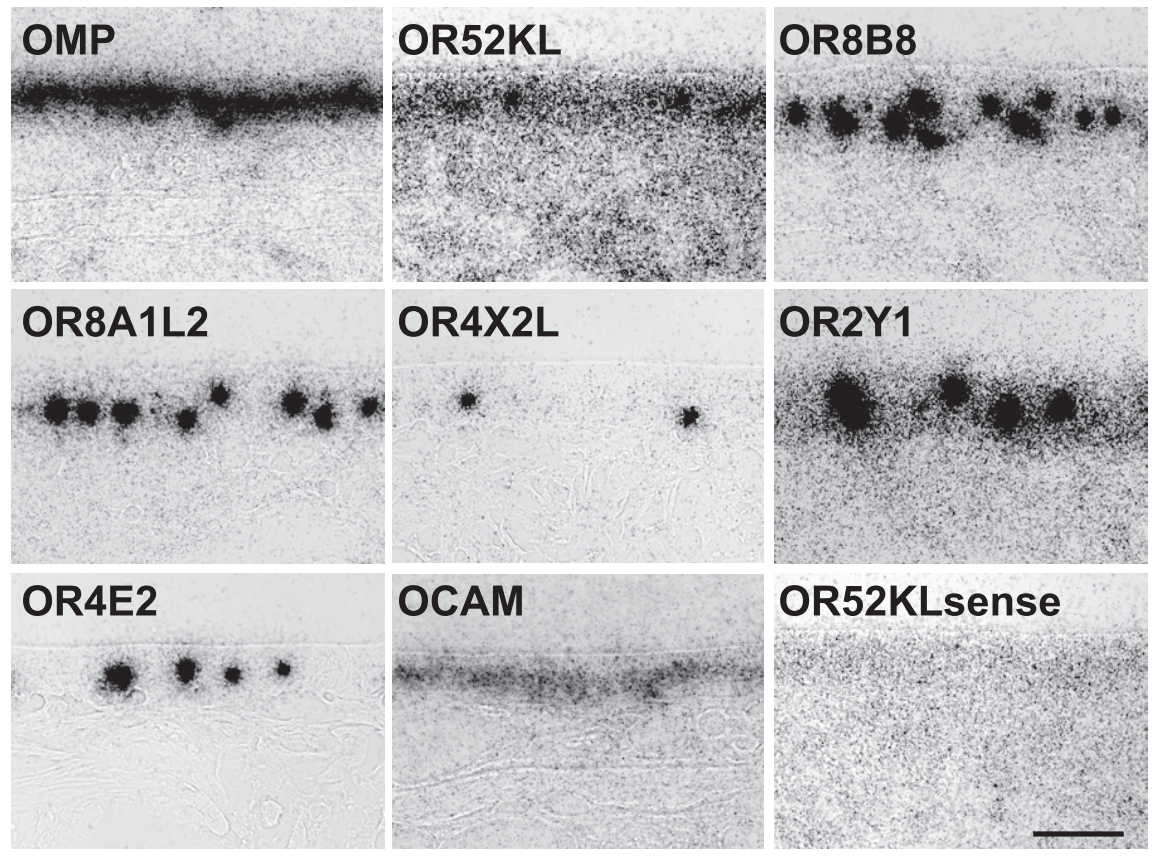

Figure 2. Macaque OR genes are expressed in small subsets of scattered OSNs. Individual OR probes hybridized to subsets of scattered OSNs whereas the OMP probe labeled OSNs throughout the OE, an OCAM probe hybridized to OSNs in certain OE regions, and a sense $0 R 52 K 2$ probe did not hybridize to 0 E cells. Scale bar, $0.1 \mathrm{~mm}$.

(Olfr552, Olfr152, and Olfr160) are expressed in dorsal-most mouse zone 1 and the remaining three (Olfr1269, Olfr10, and Olfr1509) in more ventral zones previously described as zones 2, 3, and 4, respectively (Sullivan et al., 1996; Tsuboi et al., 1999; Zheng et al., 2000; Miyamichi et al., 2005; Tsuboi et al., 2006). OR52K2L is a member of the phylogenetically distinct "Class I" set of ORs, which are mostly expressed in zone I in the mouse (Tsuboi et al., 2006). The other macaque ORs belong to the more typical Class II set. cRNA probes matching the macaque OR genes were each hybridized to sections from several anterior-posterior OE locations. Based on nucleotide sequence relationships and the hybridization conditions used, we expected OR4X2L, OR2Y1, and OR4E2OR5 probes to each hybridize to mRNAs encoded by a single OR gene, and OR52K2L, OR8B8, and OR8A1L2 probes to mRNAs encoded by 2, 4, and 2 OR genes, respectively (Table 1 ).

Each OR cRNA probe hybridized to a small subset of OSNs that were dispersed within the OE (Fig. 2). For each probe, we determined the number of hybridized OSNs in sections from different animals and the total OE surface area in each section (Table 1). Based on these data and the approximate number of total $\mathrm{OMP}^{+} \mathrm{OSN}$ in the M. mulatta OE, we estimate that the OR genes recognized by the probes are each expressed in $\sim 1 / 115$ to 1/754 OSNs (Table 1).

Thus, two basic features of OR gene expression seen in mouse are conserved in macaque. First, each OR gene is expressed in a small fraction of OSNs, suggesting that each OSN may express only a single OR gene. Second, OSNs expressing the same OR are highly distributed in the OE and those expressing different ORs are therefore interspersed.

\section{OR expression zones in macaque}

The mouse (and rat) OE has two domains defined by the expression of OCAM in OSNs: a dorsal OCAM ${ }^{-}$domain, which corresponds to the most dorsal OR expression zone (zone 1), and a ventral $\mathrm{OCAM}^{+}$domain that includes the remaining zones (Schwob and Gottlieb, 1986; Alenius and Bohm, 1997; Yoshihara et al., 1997).
We found a similar arrangement in macaque $(n=7)$. A macaque OCAM probe primarily labeled OSNs in ventral OE regions, except in very anterior and posterior areas, which were mostly $\mathrm{OCAM}^{-}$and $\mathrm{OCAM}^{+}$, respectively (Figs. 3, 4A). However, the percentage of OE that was $\mathrm{OCAM}^{+}$at three anteriorposterior locations averaged $49 \pm 8 \%$ ( $n=3$, M. mulatta), compared with $\sim 75 \%$ in mouse, suggesting that the $\mathrm{OCAM}^{-}$domain is expanded in macaque relative to mouse. In preliminary studies, antibodies to NADPH:quinone oxidoreductase (NQO1), a dorsal zone marker in other species (Gussing and Bohm, 2004), stained glomeruli in all regions of the $\mathrm{OB}$, and were thus uniformative (data not shown). This is consistent with previous histochemical studies of NADPH diaphorase activity (from NQO1) in human and macaque $\mathrm{OB}$ showing no evidence of the $\mathrm{NQO}^{-}$ventral region seen in other species (Alonso et al., 1998; Brinón et al., 1998).

Does macaque, like mouse, have OR expression zones that correlate with the OCAM domains? Neighboring OE sections were hybridized with OR and OCAM probes and the density and percentage of labeled OSNs in $\mathrm{OCAM}^{+}$and $\mathrm{OCAM}^{-}$domains were determined for each OR probe (Fig. 4; Table 1).

OSNs labeled by OR52K2L, OR8B8, OR8A1L2, and OR2Y1 probes were located predominantly in the dorsal OCAM ${ }^{-}$domain ( $96 \pm 3,90 \pm 2,86 \pm 4$, and $75 \pm 2 \%$, respectively; $n=5$ ). In contrast, OSNs expressing OR4X2 and OR4E2 were found primarily in the ventral $\mathrm{OCAM}^{+}$domain $(86 \pm 5$ and $92 \pm 3 \%$, respectively). Similar results were obtained in M. nemestrina $(n=$ 2) for $O R 8 B 8, O R 8 A 1 L 2$, and $O R 4 X 2 L$, but few cells were labeled for the other ORs. Remarkably, five of six macaque ORs showed the same rough localization to $\mathrm{OCAM}^{-}$and $\mathrm{OCAM}^{+}$domains as their mouse homologs. These results indicate that, in macaque as in mouse, there are spatial zones of OR expression that are related to OCAM expression domains.

The mouse (and rat) OE has a series of multiple, partially overlapping OR expression zones organized along the dorsalventral axis (Ressler et al., 1993; Vassar et al., 1993; Sullivan et al., 1996; Iwema et al., 2004; Miyamichi et al., 2005). Each OR gene is expressed in neurons scattered in only one zone, which typically occupies approximately one-quarter of the OE.

In contrast to what is seen in rodents, we identified only two general zones in macaque, one dorsal and one ventral. Given the proportion of the OE labeled for OCAM (approximately onehalf) and the rough correspondence between the OCAM domains and the areas that hybridized to individual OR probes, it appears that each of the OR zones seen in macaque occupies approximately one-half the $\mathrm{OE}$, as opposed to approximately one-quarter of the $\mathrm{OE}$ in the case of mouse zones. It cannot be excluded that the macaque has additional "mouse-like" zones that occupy smaller proportions of the OE. However, according to a hypergeometric distribution, this appears unlikely: if only $40 \%$ of macaque OR genes had a mouse-like expression pattern, the probability of $0 / 6$ probes showing that pattern is only 0.046 , even if each probe detected the expression of only a single gene. It 

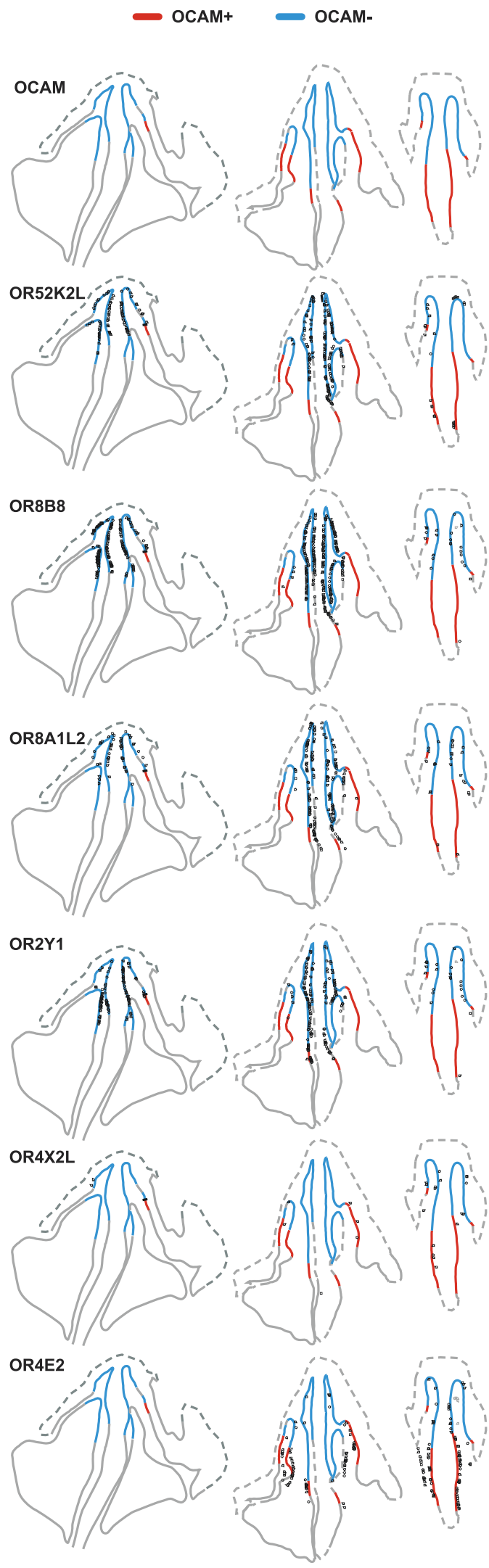

Figure 3. OR probes show differential hybridization to $\mathrm{OCAM}^{+}$and $\mathrm{OCAM}^{-}$domains. Black dots show the positions of OSNs labeled by OR probes on one to three sections superimposed on outlines showing OCAM labeling at three anterior-posterior (left to right) locations (Animal 11). Red represents $\mathrm{OCAM}^{+} / O \mathrm{MP}^{+}$regions, blue represents $\mathrm{OCAM}^{-} / \mathrm{OMP}^{+}$regions, and gray represents $\mathrm{OMP}-$ regions. Scale bar, $2 \mathrm{~mm}$. may be, however, that macaque OR zones can be slightly offset from each other and not precisely the same from OR to OR. This may be the case, for example, for the expression patterns seen for OR2Y1 versus OR52K2L (Fig. $4 F$ ).

\section{Zonal patterns of projections to the $\mathrm{OB}$}

In the mouse, innate aversive responses to certain predator and spoiled food odors require ORs expressed in zone 1, the most dorsal, OCAM ${ }^{-}$zone (Kobayakawa et al., 2007). As noted above, 5/6 macaque ORs showed the same localization to OCAM ${ }^{-}$and $\mathrm{OCAM}^{+}$domains as their mouse homologs. One question raised by these findings is whether a hard wiring of brain inputs from some ORs in a particular OE zone might provide a selective advantage that preserved the zonal expression patterns of a large contingent of ORs during evolution.

Consistent with this idea, we found that the OE-OB axonal projection in macaque has a dorsal-ventral organization similar to that in mouse. In mouse, the dorsal $\mathrm{OCAM}^{-}$and ventral $\mathrm{OCAM}^{+} \mathrm{OE}$ domains project to glomeruli in roughly corresponding dorsal-ventral domains in the bulb (Alenius and Bohm, 1997; Yoshihara et al., 1997). In macaque, OSN axons immunostained for OCAM were similarly located primarily in glomeruli in the ventral bulb, whereas the dorsal bulb contained mostly OCAM $^{-}$glomeruli (Fig. $5 ; n=5$ OBs from 3 animals). The only exceptions were glomeruli in the very anterior and posterior bulb, which were mostly $\mathrm{OCAM}^{-}$and $\mathrm{OCAM}^{+}$, respectively. Thus, in macaque as in mouse, the broad dorsal-ventral organization of gene expression in the OE defined by OCAM expression is preserved in its axonal projection to the $\mathrm{OB}$.

\section{TAAR expression in the macaque nose}

Do TAARs function as olfactory receptors in macaque, as they do in mouse? To explore this question, we hybridized probes for each of the 6 intact macaque TAAR genes (TAAR1-TAAR6) to macaque $\mathrm{OE}$ sections using conditions that distinguish the expression of different TAARs (Fig. 6; Table 2).

As in mouse, we saw little or no evidence for TAAR1 expression in the macaque OE. However, probes for TAAR2-TAAR6 each hybridized to a small subpopulation of OSNs that were scattered in the OE (Fig. 6). With the exception of TAAR4, far fewer OSNs were labeled by TAAR than by OR probes in M. mulatta (1/561 OSNs for TAAR4, 1/3860-1/7284 OSNs for other TAARs; Fig. 2; Table 2). However, the densities of OSNs labeled for TAARs and several ORs were similar in M. nemestrina. The low-frequency of TAAR ${ }^{+}$OSNs in many animals prevented analysis of their relative densities in $\mathrm{OCAM}^{+}$and OCAM $^{-}$domains, but in 3/4 M. mulatta it appeared that TAAR4 ${ }^{+}$ OSNs were present at similar densities in the two domains (Fig. $4 B-E$; Table 2). These results indicate that TAARs are indeed expressed by OSNs in the OE of a higher primate and may therefore also be expressed in the human OE.

\section{A human TAAR associated with spoiled food}

What chemosensory stimuli do macaque and human TAARs detect? We previously conducted a chemical screen of mouse TAARs (mTAARs) and human TAARs (hTAARs) expressed in HEK293 cells using low concentrations of $>200$ diverse odorants (Liberles and Buck, 2006). We identified ligands for several mTAARs, all of which were amines, but none for hTAARs.

To further search for hTAAR ligands, we expressed all individual hTAARs (except TAAR1) in HEK293 cells and assessed their responses to different amines using a cAMP reporter assay based on SEAP. We tested 178 amines, including many not previously tested, at higher concentrations ( 30 and $300 \mu \mathrm{M}$ ) than we had previously. 
A

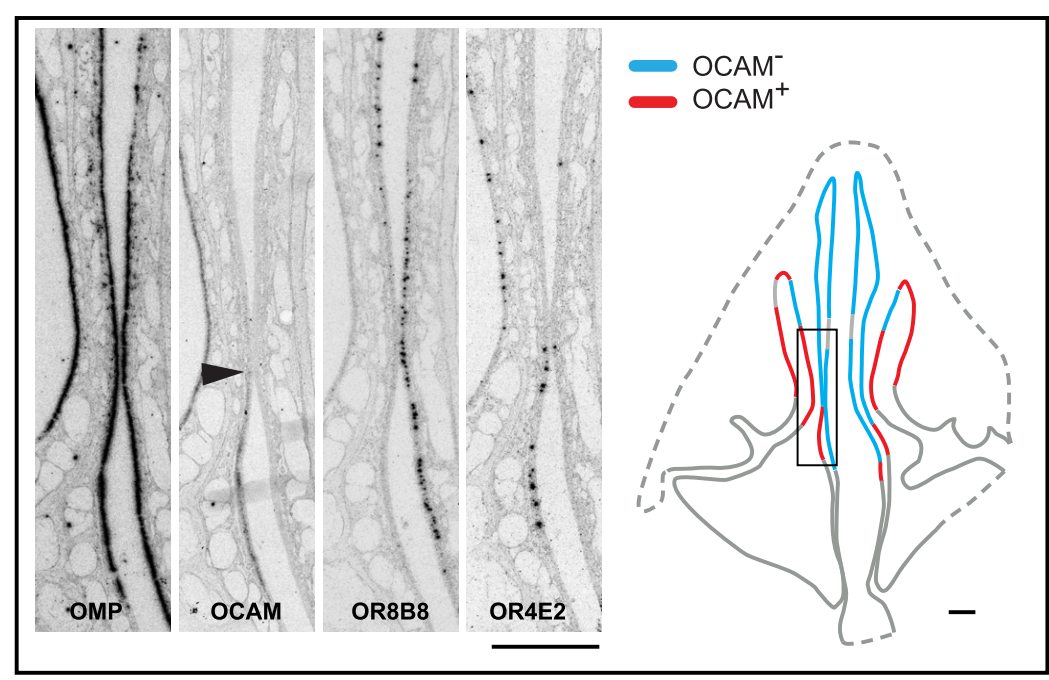

B

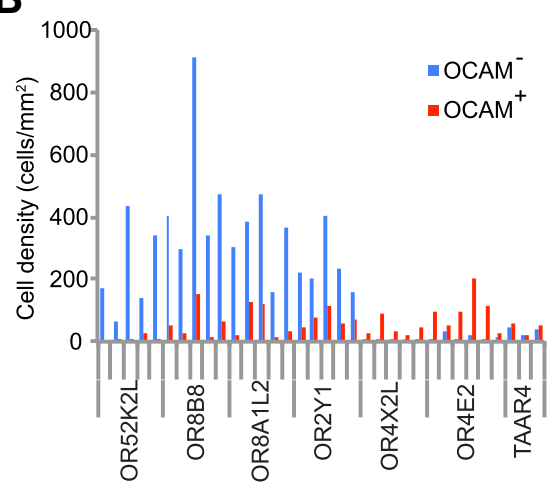

D
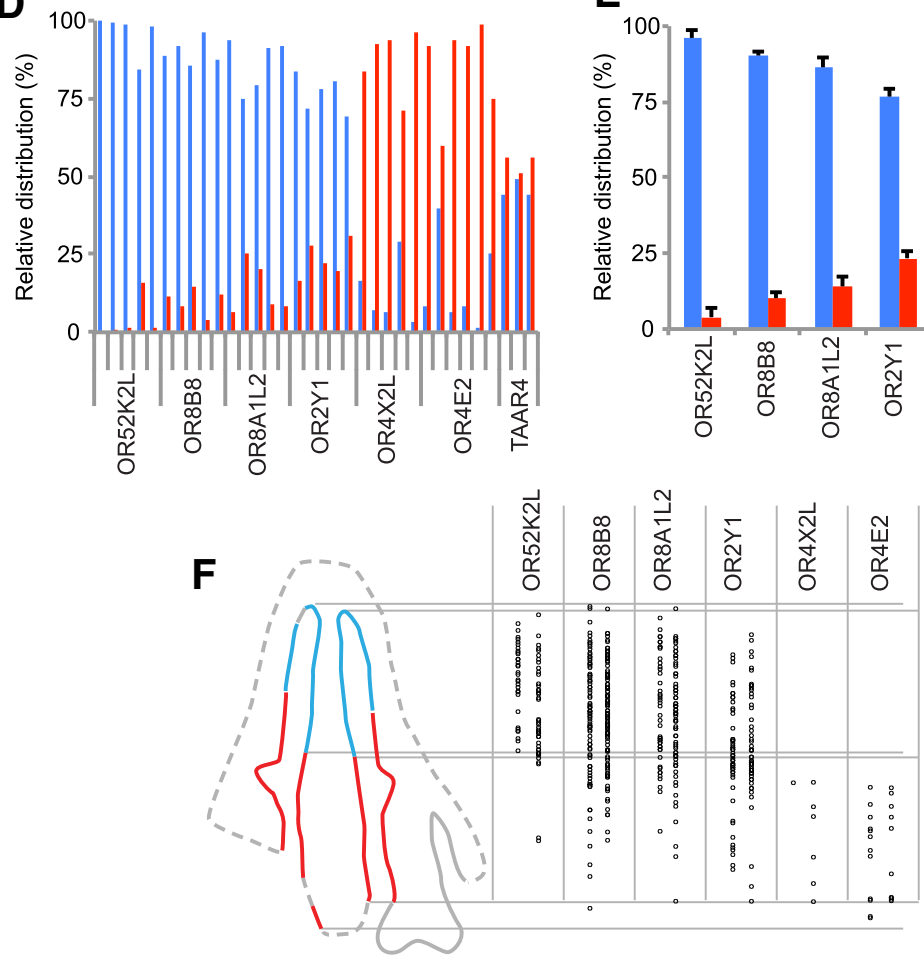

Figure 4. Two major zones of OR expression in macaque. $\boldsymbol{A}$, Hybridization of the indicated probes to the boxed area shown at right. 0 n the right side of the turbinate, OCAM labeling is seen below the arrowhead. OSNs labeled by $O R 8 B$ and $O R 4 E 2$ probes were located primarily in $\mathrm{OCAM}^{-}$and $\mathrm{OCAM}^{+}$regions, respectively. $\boldsymbol{B}-\boldsymbol{E}$, Graphs show the average cell density $(\boldsymbol{B}, \boldsymbol{C})$ and relative distribution in $\mathrm{OCAM}^{+}$and $\mathrm{OCAM}^{-}$domains $(\boldsymbol{D}, \boldsymbol{E})$ of OSNs labeled for different ORs and TAAR4 in individual M. mulatta animals
We found only that hTAAR5 recognizes the mTAAR5 ligand, TMA, as recently reported (Wallrabenstein et al., 2013; Zhang J. et al., 2013; Fig. 7A). We found that macaque TAAR5 and not other macaque TAARs also responded to TMA (Fig. 7A). However, we did not find ligands for any other macaque TAAR in a preliminary screen in which we tested all intact macaque TAARs except TAAR1.

Like some mTAARs, hTAARs could conceivably detect animal-associated cues, perhaps including amines in human secretions. However, because bacteria generate amines during spoilage of food (Naila et al., 2010), we reasoned that food might be another source of amines important for humans, and perhaps also macaques. By screening hTAARs with extracts prepared from fresh or spoiled foods, we found that hTAAR 5 responds to rotten salmon, but not to fresh salmon (Fig. 7B). A small response was also sometimes seen to spoiled, but not fresh beef, whereas preliminary experiments showed no response to fresh or spoiled tomato (data not shown). No significant responses were seen with macaque TAARs, including macaque TAAR5, which also had a weaker response to TMA than did human TAAR5. Interestingly, the unpleasant characteristic smell of rotten fish is thought to mainly derive from TMA generated by bacteria during spoilage (Gram and Dalgaard, 2002). The smell of both TMA and spoiled food are generally repugnant to humans (Mitchell and Smith, 2001), suggesting that, like some TAAR ligands in mouse and zebrafish (Ferrero et al., 2011; Dewan et al., 2013; Hussain et al., 2013), human TAAR5 ligands may elicit innate aversive responses.

\section{Discussion}

Previous studies using OR genes have provided insight into the molecular mechanisms and organizational strategies that underlie odor sensing in mice. Here we investigated whether these strategies are evolutionarily conserved in macaque, a higher primate phylogenetically close to humans. These studies showed that certain features of OR gene expression are common to macaque and mouse, as is the

\section{$\leftarrow$}

$(\boldsymbol{B}, \boldsymbol{D})$, and as averages $\pm \operatorname{SEM}(\boldsymbol{C}, E ; O R S, n=5 ; \operatorname{TAAR} 4, n=$ 4). $\boldsymbol{F}$, The locations of OR-labeled OSNs (black dots) relative to OCAM labeling is shown in linearized form for the two sides of the nasal septum (Animal 10). Red represents $\mathrm{OCAM}^{+} /$ $\mathrm{OMP}^{+}$regions, blue represents $0 \mathrm{CAM}^{-} / \mathrm{MMP}^{+}$regions, and gray represents $0 \mathrm{MP}^{-}$regions. Student unpaired $t$ test; ${ }^{*} p<$ $0.05,{ }^{* *} p<0.01,{ }^{* * *} p<0.005$. Scale bars: $A, F, 1 \mathrm{~mm}$. 

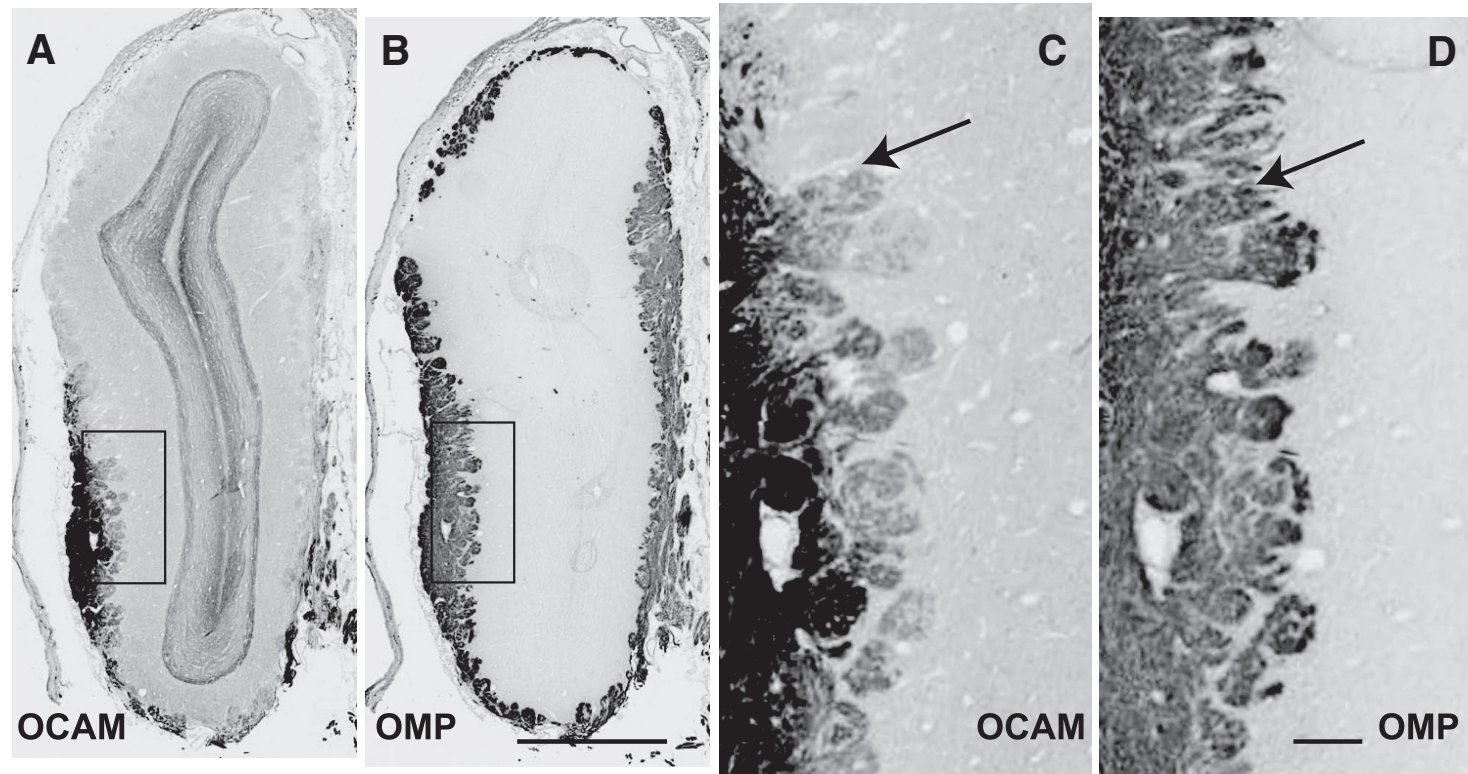

Figure 5. Patterning in the olfactory epithelium to bulb projection. Adjacent coronal sections of macaque OB were immunostained for OSN axons using antibodies to OMP or OCAM. OMP ${ }^{+}$axons are seen in the olfactory nerve layer on the bulb surface and in spheroid glomeruli just below the surface. $0 \mathrm{CAM}^{+}$axons are seen primarily in the ventral bulb, particularly the ventrolateral part at left $\left(\boldsymbol{A}, \boldsymbol{C}\right.$ ). In higher-magnification views of the boxed regions $(\boldsymbol{C}, \boldsymbol{D})$, arrows mark the transition between $\mathrm{OCAM}^{-}$and $\mathrm{OCAM}^{+}$glomeruli (Animal 13$)$. Scale bars: $\boldsymbol{A}, \boldsymbol{B}, 1 \mathrm{~mm} ; \boldsymbol{C}, \boldsymbol{D}, 0.1 \mathrm{~mm}$.

A

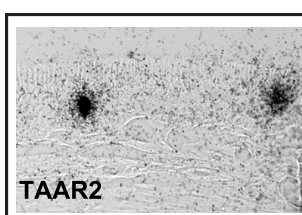

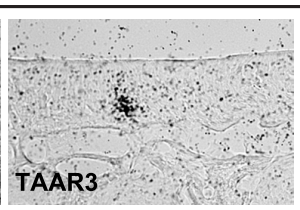

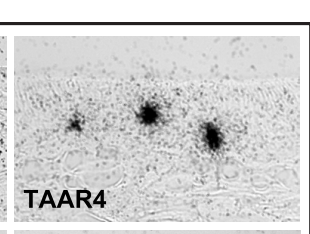

TAAR4

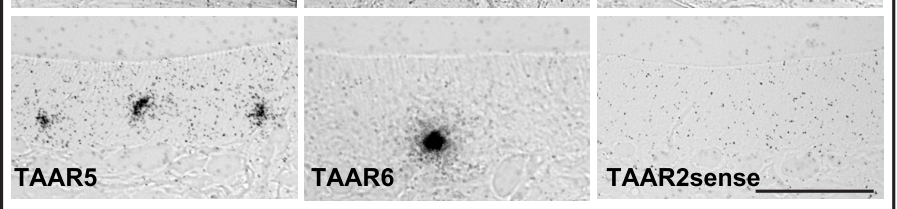

B

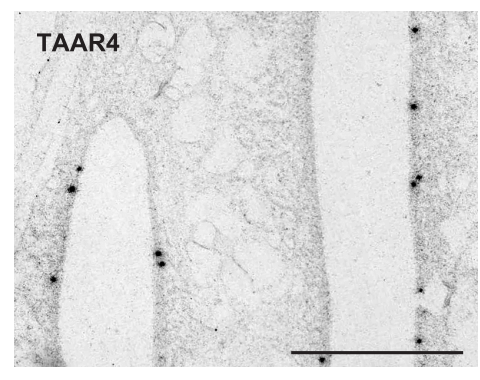

TAAR5

TAAR6
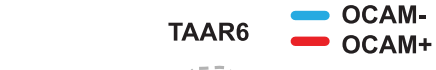

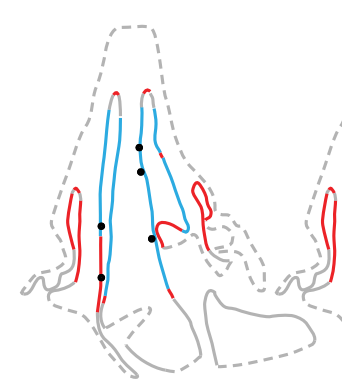

TAAR3

TAAR4<smiles>C1=CC2C=CCC2=C1</smiles>

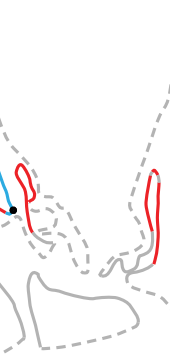

(1)

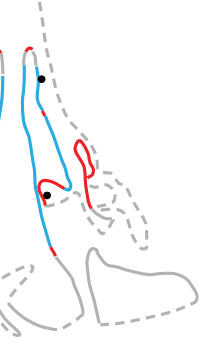

Figure 6. TAAR gene expression in macaque olfactory epithelium. CRNA probes for TAAR2-TAAR6 each hybridized to a small subpopulation of OSNs that were dispersed in the OE, whereas no labeling was seen with a TAAR2 sense probe $(\boldsymbol{A})$. OSNs labeled for TAAR4 were located in both OCAM ${ }^{-}$and $O C A M{ }^{+}$regions in the boxed region indicated in $(\boldsymbol{B}, \boldsymbol{C})$. The locations of 0 SNs labeled by TAAR probes are shown as black dots in (C). Animal 10 . Scale bars: $\boldsymbol{A}, 0.1 \mathrm{~mm} ; \boldsymbol{B}, 1 \mathrm{~mm} ; \boldsymbol{C}, 2 \mathrm{~mm}$.

existence of dorsal and ventral OE domains that differ in OCAM expression and project axons to corresponding dorsal-ventral domains in the $\mathrm{OB}$. However, the organization of the $\mathrm{OE}$ into multiple discrete OR expression zones in mouse appears to be replaced in macaque by a simplified arrangement composed of two broad domains expressing different sets of OR genes. These studies further show that 5/6 macaque TAAR genes are expressed in the $\mathrm{OE}$ and are thus likely to function as olfactory receptors in this species, and most likely other primates, including humans. They also demonstrate that one human TAAR responds to spoiled fish, a natural source of aversive odorants.

\section{OR gene expression in macaque versus mouse}

Prior human studies of ORs or TAARs could not address questions about their spatial expression in OSNs in the nose because those studies used homogenized nasal tissues (Zhang X. et al., 
Table 2. TAAR gene expression in macaque $\mathrm{OE}$

\begin{tabular}{|c|c|c|c|c|c|c|c|}
\hline & Animal $^{a}$ & No. of $\mathrm{CCAM}^{-}$cells & OCAM- density $^{b}$ & No. of $\mathrm{OCAM}^{+}$cells & OCAM $^{+}$density $^{b}$ & $\mathrm{OCAM}^{-}(\%)$ & Fraction of OSNs \\
\hline \multirow[t]{8}{*}{ TAAR1 } & 6 & 0 & 0 & 0 & 0 & & \\
\hline & 10 & 0 & 0 & 0 & 0 & & \\
\hline & 11 & 7 & 1.3 & 1 & 0.2 & & \\
\hline & 13 & & & & & & \\
\hline & Avg & & $0.4 \pm 0.4$ & & $0.1 \pm 0.1$ & & \\
\hline & 8 & 10 & 5.1 & 1 & 1.6 & 76 & \\
\hline & 12 & 0 & 0 & 0 & 0 & & \\
\hline & Avg & & 2.5 & & 0.8 & & \\
\hline \multirow[t]{8}{*}{ TAAR2 } & 6 & 4 & 3.2 & 0 & 0 & & \\
\hline & 10 & 10 & 4.0 & 4 & 2.6 & & \\
\hline & 11 & 31 & 7.9 & 12 & 5.0 & 61 & \\
\hline & 13 & 9 & 8.3 & 16 & 7.3 & 53 & \\
\hline & Avg & & $5.9 \pm 1.3$ & & $3.7 \pm 1.6$ & 57 & $1 / 3860$ \\
\hline & 8 & 143 & 44 & 17 & 16 & 73 & \\
\hline & 12 & 43 & 21 & 2 & 5.1 & 81 & \\
\hline & Avg & & 32.8 & & 10.7 & 77 & $1 / 847$ \\
\hline \multirow[t]{8}{*}{ TAAR3 } & 6 & 2 & 0.9 & 0 & 0 & & \\
\hline & 10 & 8 & 3.2 & 5 & 3.3 & & \\
\hline & 11 & 38 & 8.5 & 10 & 3.9 & 68 & \\
\hline & 13 & 9 & 8.3 & 10 & 4.6 & & \\
\hline & Avg & & $5.2 \pm 1.9$ & & $2.9 \pm 1$ & & $1 / 4521$ \\
\hline & 8 & 27 & 17 & 6 & 11 & 62 & \\
\hline & 12 & 71 & 35 & 8 & 20 & 63 & \\
\hline & Avg & & 26.1 & & 15.6 & 62 & $1 / 888$ \\
\hline \multirow[t]{8}{*}{ TAAR4 } & 6 & 13 & 8.9 & 8 & 26 & 25 & \\
\hline & 10 & 113 & 45 & 88 & 57 & 44 & \\
\hline & 11 & 85 & 19 & 46 & 19 & 49 & \\
\hline & 13 & 43 & 40 & 110 & 50 & 44 & \\
\hline & Avg & & $28.2 \pm 8.6$ & & $38.2 \pm 9.2$ & $41 \pm 5$ & $1 / 561$ \\
\hline & 8 & 76 & 71 & 7 & 14 & 84 & \\
\hline & 12 & 270 & 132 & 31 & 79 & 63 & \\
\hline & Avg & & 101.6 & & 46.5 & 73 & $1 / 249$ \\
\hline \multirow[t]{8}{*}{ TAAR5 } & 6 & 2 & 2.0 & 0 & 0 & & \\
\hline & 10 & 11 & 4.4 & 1 & 0.7 & & \\
\hline & 11 & 19 & 3.8 & 2 & 0.7 & 84 & \\
\hline & 13 & 10 & 9.2 & 6 & 2.7 & & \\
\hline & Avg & & $4.9 \pm 1.5$ & & $1.0 \pm 0.6$ & & $1 / 6231$ \\
\hline & 8 & 125 & 6 & 13 & 10.0 & 37 & \\
\hline & 12 & 10 & 4.9 & 0 & 0.0 & & \\
\hline & Avg & & 5.4 & & 5.0 & & $1 / 3560$ \\
\hline \multirow[t]{8}{*}{ TAAR6 } & 6 & 3 & 1.5 & 2 & 5.1 & & \\
\hline & 10 & 11 & 4.4 & 5 & 3.3 & 58 & \\
\hline & 11 & 1 & 0.3 & 1 & 0.4 & & \\
\hline & 13 & 4 & 3.7 & 4 & 1.8 & & \\
\hline & Avg & & $2.5 \pm 1$ & & $2.6 \pm 1$ & & $1 / 7284$ \\
\hline & 8 & 27 & 15 & 1 & 1.5 & 91 & \\
\hline & 12 & 98 & 48 & 4 & 10 & 82 & \\
\hline & Avg & & 31.6 & & 5.8 & 87 & $1 / 981$ \\
\hline
\end{tabular}

In situ hybridization data are shown for six TAAR probes.

${ }^{a}$ M. mulatta: Animals 6, 9, 10, 11, and 13; M. nemestrina: Animals 8 and 12 .

${ }^{b}$ Density of hybridized neurons in 0 E after overcounting correction and given as labeled cells $/ \mathrm{mm}^{2} \mathrm{OE}$ surface area, Avg \pm SEM. Total density assuming $51 \% 0$ OAM ${ }^{+}$(see Materials and Methods). TAAR/animal combinations with $<20$ cells are not included. The estimated total OSN cell density is 18,590 (see Materials and Methods)

2007; Carnicelli et al., 2010). Our in situ hybridization studies show that several fundamental features of OR gene expression in the mouse are present in a higher primate. First, each OR gene is expressed in a small subset of neurons, suggesting that each macaque OSN may express a single OR gene and thus transmit signals to the brain that reflect the odorant specificities of a single receptor type. Second, macaque OSNs with the same OR are highly distributed within a specific OE spatial zone, suggesting that the developing neuron uses a stochastic mechanism to select one OR gene for expression from a spatially appropriate subset of OR genes.

Two additional features that are evolutionarily conserved in macaque are the division of the OE into dorsal and ventral domains distinguished by the expression of OCAM, and the projec- 


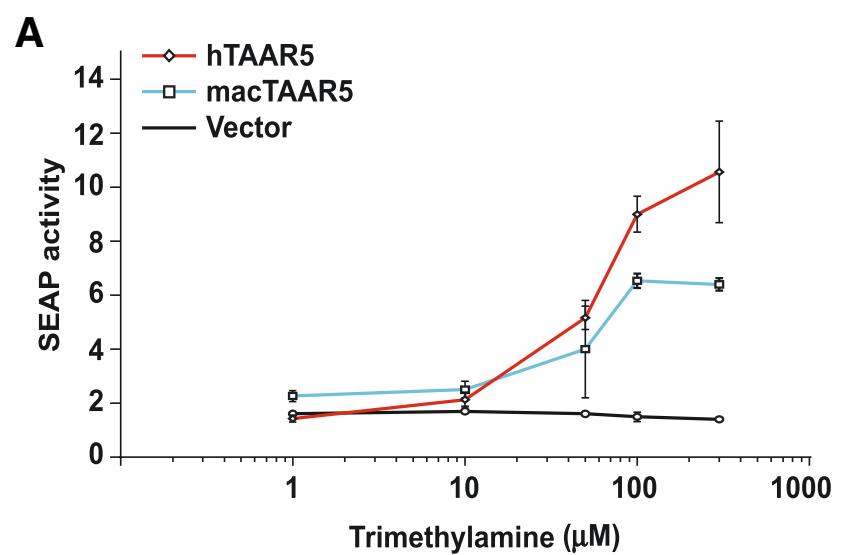

B

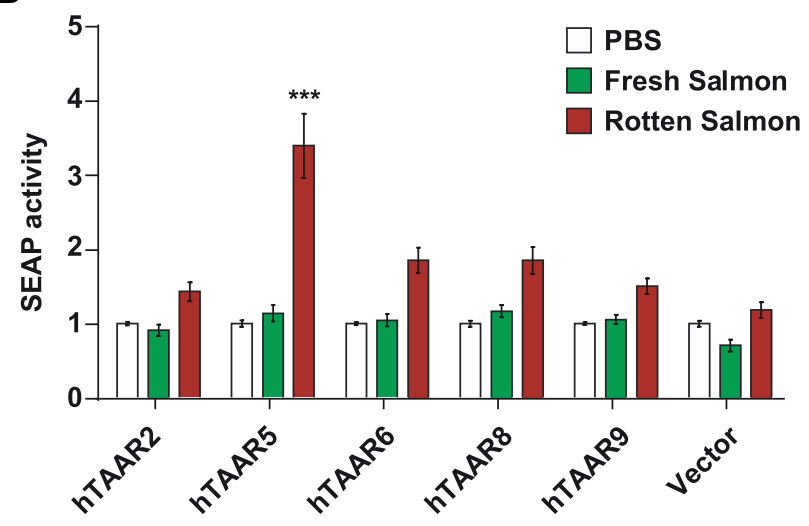

Figure 7. TAAR5 responds to TMA and spoiled fish. Human and macaque receptors were heterologously expressed in HEK293 cells cotransfected with a CRE-SEAP vector, and their activation was monitored by a SEAP assay. Dose-response curves for human and macaque TAAR5 to TMA are shown in $\boldsymbol{A}$, with an $\mathrm{EC}_{50}$ of 59 and $55 \mu \mathrm{M}$, respectively. Average $\pm \mathrm{SEM}, n=3$. Human TAAR5 responds to spoiled but not to fresh salmon (diluted 1:30) (B). Average \pm SEM, $n=12 ;{ }^{* * *} p<0.0001$ Student's $t$ test for responses compared with that of the vector. SEAP activity given relative to no ligand control.

tion of axons from those domains to corresponding dorsal and ventral domains in the OB. Surprisingly, most macaque OR genes examined were expressed in the same OCAM domain as their closest mouse homologs, suggesting that the conserved projection patterns of the OCAM domains extends beyond the domains to a preservation of signaling from specific types of receptors to selected regions of the bulb.

Given that some mouse-primate OR orthologs recognize the same or similar odorants (Adipietro et al., 2012), these findings suggest that sensory signals generated by certain types of odorants may be transmitted to the same bulb domain in mice and primates. Interestingly, ablation of the dorsal OCAM ${ }^{-} \mathrm{OE}$ domain in mice results in a loss of innate aversive responses to a number of odorants (Kobayakawa et al., 2007). In addition, the dorsal and ventral bulb appear to have slightly different projections to the amygdala, an area involved in innate behaviors (Kang et al., 2009, 2011; Miyamichi et al., 2011). It seems unlikely that all ORs expressed in the dorsal OCAM ${ }^{-}$domain stimulate aversion in either mouse or macaque. However, it is conceivable that certain features of the $\mathrm{OE}$ to $\mathrm{OB}$ axonal projection, such as the transmission of signals from certain classes of ORs, have been evolutionarily conserved due to their ability to elicit innately aversive or pleasurable responses to particular functionally significant odorants. For example, such signals might alert the ani- mal to foods that pose a danger if ingested or ones that would provide caloric value, such as sweet foods.

Considering the numerous conserved features of olfactory inputs noted above, it is curious that the zonal organization of $\mathrm{OR}$ gene expression in the OE seems quite different in macaque and mouse. The mouse has a series of OR zones organized along the dorsal-ventral axis, each of which appears to cover approximately one-quarter the OE. In contrast, we identified only two broad zones in macaque that roughly correspond to the dorsal and ventral OCAM domains. It may be that there are slight differences in the dorsal and ventral boundaries of the zones occupied by different ORs in, for example, the dorsal OCAM ${ }^{-}$domain. However, each OR is predominantly expressed in an area covering approximately one-half the OE rather than approximately onequarter of the $\mathrm{OE}$ as seen for many mouse ORs.

These findings suggest that a zonal organization present in a common rodent/primate ancestor might have either degenerated in primates or become more complex in rodents. The functional significance of OR expression zones is currently unknown. However, the present studies suggest that the macaque not only has fewer OR genes than mouse, but may also have fewer OR expression zones, each covering a larger proportion of the OE than seen for OR zones in mouse. The apparent correlation between OR gene number and zones raises the possibility that the two might be interrelated. It is conceivable, for example, that the number of OR zones reflects an upper limit on the number of OR genes from which the developing OSN can select to achieve the expression of a single OR gene. In this scenario, the locations of the zones might simply reflect evolutionary events in which OSN progenitors at different locations became marked with different zonal identities. In this model, the different zonal identities would then serve to restrict the OSN offspring of differently marked progenitors to randomly select a single OR gene for expression from a different zonal OR gene set.

\section{TAARs as chemosensory receptors in primates}

These studies suggest that TAARs serve as olfactory receptors not only in mice and fish, but also in macaque, and may therefore also do so in humans. Although the TAAR family is evolutionarily conserved from fish to humans, reports of TAAR expression in the brain (Vanti et al., 2003) and other tissues in humans raised the possibility that primate TAARs might instead have other functions (Lewin, 2006). However, the present studies show that five of six macaque TAARs are expressed in small subsets of dispersed OSNs in the macaque OE, a patterning similar to that seen for both ORs and TAARs in mouse and for ORs in macaque. Whether some or all macaque TAARs have additional, nonolfactory functions in other tissues is unknown.

One puzzling question is why TAARs have persisted as olfactory receptors over vertebrate evolution. The large size of the OR family and its combinatorial use in odor coding easily account for the ability to detect and discriminate a virtually unlimited number of odorants. Moreover, like at least some TAARs, some ORs respond to amines when expressed in HEK293 cells (K. Nara, Z. Lu, E. Lee, L.B.B., unpublished observation). This would seem to argue against the remote possibility that TAARs have been evolutionarily conserved to detect amine odorants because amines cannot be recognized by ORs. Optical imaging studies of the dorsal OB also suggest the activation of ORs as well as TAARs by amines, although TAARs may be more sensitive to low concentrations of certain amines than are ORs (Pacifico et al., 2012; Zhang J. et al., 2013).

One potential clue comes from our finding that human TAAR5 is activated by extracts of rotten fish, which has an odor 
typically repulsive to humans. Preliminary studies suggest that several mouse TAARs, including mTAAR5, also respond to spoiled fish (K-h.Y, L.R.S, L.B.B., unpublished observation). Human TAAR5 also recognizes the mTAAR5 ligand TMA, which is attractive to mice ( $\mathrm{Li}$ et al., 2013), but intensely aversive to humans (Mitchell and Smith, 2001). Indeed, in "fish malodor syndrome" (trimethylaminuria), humans unable to convert TMA to an odorless oxide have excessive TMA in bodily secretions, a condition that can repel others (Mitchell and Smith, 2001). Interestingly, ligands for two mouse TAARs (mTAAR3 and mTAAR4) are aversive to mice (Ferrero et al., 2011; Dewan et al., 2013), and mice lacking those TAARs fail to show aversion to the ligands (Dewan et al., 2013). In addition, an agonist for one zebrafish TAAR is aversive to the fish (Hussain et al., 2013).

Together, these findings raise the possibility that TAARs have been evolutionarily conserved due to a specialized ability to elicit innate responses, such as avoidance. The functional significance of these responses could vary among animals. For example, aversive responses of mice to 2-beta-phenylethylamine, a mouse TAAR4 ligand present in some carnivore urines, could aid in predator avoidance (Ferrero et al., 2011; Dewan et al., 2013). In contrast, the activation of human TAAR5 by spoiled fish might discourage the ingestion of foods that could harbor pathogenic microorganisms that pose a danger to health.

\section{References}

Adipietro KA, Mainland JD, Matsunami H (2012) Functional evolution of mammalian odorant receptors. PLoS Genet 8:e1002821. CrossRef Medline

Alenius M, Bohm S (1997) Identification of a novel neural cell adhesion molecule-related gene with a potential role in selective axonal projection. J Biol Chem 272:26083-26086. CrossRef Medline

Alonso JR, Porteros A, Crespo C, Arévalo R, Brinón JG, Weruaga E, Aijón J (1998) Chemical anatomy of the macaque monkey olfactory bulb: NADPH-diaphorase/nitric oxide synthase activity. J Comp Neurol 402: 419-434. CrossRef Medline

Brinón JG, Crespo C, Weruaga E, Alonso J, Sobreviela T, Aijón J, Alonso JR (1998) NADPH-diaphorase/nitric oxide synthase-positive elements in the human olfactory bulb. Neuroreport 9:3141-3146. CrossRef Medline

Buck L, Axel R (1991) A novel multigene family may encode odorant receptors: a molecular basis for odor recognition. Cell 65:175-187. CrossRef Medline

Buck LB, Bargmann C (2012) Smell and taste: the chemical senses. In: Principles of neuroscience (Kandel E, Schwartz J, Jessell T, Siegelbaum S, Hudspeth AJ, eds), pp 712-742. New York: McGraw-Hill.

Carnicelli V, Santoro A, Sellari-Franceschini S, Berrettini S, Zucchi R (2010) Expression of trace amine-associated receptors in human nasal mucosa. Chem Percept 3:99-107. CrossRef

Chess A, Simon I, Cedar H, Axel R (1994) Allelic inactivation regulates olfactory receptor gene expression. Cell 78:823-834. CrossRef Medline

Dewan A, Pacifico R, Zhan R, Rinberg D, Bozza T (2013) Non-redundant coding of aversive odours in the main olfactory pathway. Nature 497: 486-489. CrossRef Medline

Ferrero DM, Lemon JK, Fluegge D, Pashkovski SL, Korzan WJ, Datta SR, Spehr M, Fendt M, Liberles SD (2011) Detection and avoidance of a carnivore odor by prey. Proc Natl Acad Sci U S A 108:11235-11240. CrossRef Medline

Gloriam DE, Bjarnadóttir TK, Yan YL, Postlethwait JH, Schiöth HB, Fredriksson R (2005) The repertoire of trace amine G-protein-coupled receptors: large expansion in zebrafish. Mol Phylogenet Evol 35:470-482. CrossRef Medline

Glusman G, Yanai I, Rubin I, Lancet D (2001) The complete human olfactory subgenome. Genome Res 11:685-702. CrossRef Medline

Godfrey PA, Malnic B, Buck LB (2004) The mouse olfactory receptor gene family. Proc Natl Acad Sci U S A 101:2156-2161. CrossRef Medline

Gram L, Dalgaard P (2002) Fish spoilage bacteria: problems and solutions. Curr Opin Biotechnol 13:262-266. CrossRef Medline

Gussing F, Bohm S (2004) NQO1 activity in the main and the accessory olfactory systems correlates with the zonal topography of projection maps. Eur J Neurosci 19:2511-2518. CrossRef Medline

Hussain A, Saraiva LR, Ferrero DM, Ahuja G, Krishna VS, Liberles SD, Korsching SI (2013) High-affinity olfactory receptor for the deathassociated odor cadaverine. Proc Natl Acad Sci U S A 110:19579-19584. CrossRef Medline

Iwema CL, Fang H, Kurtz DB, Youngentob SL, Schwob JE (2004) Odorant receptor expression patterns are restored in lesion-recovered rat olfactory epithelium. J Neurosci 24:356-369. CrossRef Medline

Janecka JE, Miller W, Pringle TH, Wiens F, Zitzmann A, Helgen KM, Springer MS, Murphy WJ (2007) Molecular and genomic data identify the closest living relative of primates. Science 318:792-794. CrossRef Medline

Kajiya K, Inaki K, Tanaka M, Haga T, Kataoka H, Touhara K (2001) Molecular bases of odor discrimination: reconstitution of olfactory receptors that recognize overlapping sets of odorants. J Neurosci 21:6018-6025. Medline

Kang N, Baum MJ, Cherry JA (2009) A direct main olfactory bulb projection to the "vomeronasal" amygdala in female mice selectively responds to volatile pheromones from males. Eur J Neurosci 29:624-634. CrossRef Medline

Kang N, Baum MJ, Cherry JA (2011) Different profiles of main and accessory olfactory bulb mitral/tufted cell projections revealed in mice using an anterograde tracer and a whole-mount, flattened cortex preparation. Chem Senses 36:251-260. CrossRef Medline

Kobayakawa K, Kobayakawa R, Matsumoto H, Oka Y, Imai T, Ikawa M, Okabe M, Ikeda T, Itohara S, Kikusui T, Mori K, Sakano H (2007) Innate versus learned odour processing in the mouse olfactory bulb. Nature 450:503-508. CrossRef Medline

Lewin AH (2006) Receptors of mammalian trace amines. Aaps J 8:E138 145. CrossRef Medline

Li Q, Korzan WJ, Ferrero DM, Chang RB, Roy DS, Buchi M, Lemon JK, Kaur AW, Stowers L, Fendt M, Liberles SD (2013) Synchronous evolution of an odor biosynthesis pathway and behavioral response. Curr Biol 23:1120. CrossRef Medline

Liberles SD, Buck LB (2006) A second class of chemosensory receptors in the olfactory epithelium. Nature 442:645-650. CrossRef Medline

Mackay-Sim A, Kittel PW (1991) On the life span of olfactory receptor neurons. Eur J Neurosci 3:209-215. CrossRef Medline

Malnic B, Hirono J, Sato T, Buck LB (1999) Combinatorial receptor codes for odors. Cell 96:713-723. CrossRef Medline

Malnic B, Godfrey PA, Buck LB (2004) The human olfactory receptor gene family. Proc Natl Acad Sci U S A 101:2584-2589. CrossRef Medline

Margolis FL (1982) Olfactory marker protein (OMP). Scand J Immunol Suppl 9:181-199. Medline

Mitchell SC, Smith RL (2001) Trimethylaminuria: the fish malodor syndrome. Drug Metab Dispos 29:517-521. Medline

Miyamichi K, Serizawa S, Kimura HM, Sakano H (2005) Continuous and overlapping expression domains of odorant receptor genes in the olfactory epithelium determine the dorsal/ventral positioning of glomeruli in the olfactory bulb. J Neurosci 25:3586-3592. CrossRef Medline

Miyamichi K, Amat F, Moussavi F, Wang C, Wickersham I, Wall NR, Taniguchi H, Tasic B, Huang ZJ, He Z, Callaway EM, Horowitz MA, Luo L (2011) Cortical representations of olfactory input by trans-synaptic tracing. Nature 472:191-196. CrossRef Medline

Mombaerts P (2004) Genes and ligands for odorant, vomeronasal and taste receptors. Nat Rev Neurosci 5:263-278. CrossRef Medline

Mombaerts P, Wang F, Dulac C, Chao SK, Nemes A, Mendelsohn M, Edmondson J, Axel R (1996) Visualizing an olfactory sensory map. Cell 87:675-686. CrossRef Medline

Munger SD, Leinders-Zufall T, Zufall F (2009) Subsystem organization of the mammalian sense of smell. Annu Rev Physiol 71:115-140. CrossRef Medline

Naila A, Flint S, Fletcher G, Bremer P, Meerdink G (2010) Control of biogenic amines in food: existing and emerging approaches. J Food Sci 75: R139-R150. CrossRef Medline

Niimura Y, Nei M (2005) Comparative evolutionary analysis of olfactory receptor gene clusters between humans and mice. Gene 346:13-21. CrossRef Medline

Niimura Y, Nei M (2007) Extensive gains and losses of olfactory receptor genes in mammalian evolution. PLoS One 2:e708. CrossRef Medline

Pacifico R, Dewan A, Cawley D, Guo C, Bozza T (2012) An olfactory sub- 
system that mediates high-sensitivity detection of volatile amines. Cell Rep 2:76-88. CrossRef Medline

Pomeroy SL, LaMantia AS, Purves D (1990) Postnatal construction of neural circuitry in the mouse olfactory bulb. J Neurosci 10:1952-1966. Medline

Ressler KJ, Sullivan SL, Buck LB (1993) A zonal organization of odorant receptor gene expression in the olfactory epithelium. Cell 73:597-609. CrossRef Medline

Ressler KJ, Sullivan SL, Buck LB (1994) Information coding in the olfactory system: evidence for a stereotyped and highly organized epitope map in the olfactory bulb. Cell 79:1245-1255. CrossRef Medline

Schwob JE, Gottlieb DI (1986) The primary olfactory projection has two chemically distinct zones. J Neurosci 6:3393-3404. Medline

Smith RL, Baker H, Kolstad K, Spencer DD, Greer CA (1991) Localization of tyrosine hydroxylase and olfactory marker protein immunoreactivities in the human and macaque olfactory bulb. Brain Res 548:140-148. CrossRef Medline

Sullivan SL, Adamson MC, Ressler KJ, Kozak CA, Buck LB (1996) The chromosomal distribution of mouse odorant receptor genes. Proc Natl Acad Sci U S A 93:884-888. CrossRef Medline

Tsuboi A, Yoshihara S, Yamazaki N, Kasai H, Asai-Tsuboi H, Komatsu M, Serizawa S, Ishii T, Matsuda Y, Nagawa F, Sakano H (1999) Olfactory neurons expressing closely linked and homologous odorant receptor genes tend to project their axons to neighboring glomeruli on the olfactory bulb. J Neurosci 19:8409-8418. Medline

Tsuboi A, Miyazaki T, Imai T, Sakano H (2006) Olfactory sensory neurons expressing class I odorant receptors converge their axons on an anterodorsal domain of the olfactory bulb in the mouse. Eur J Neurosci 23: 1436-1444. CrossRef Medline
Vanti WB, Muglia P, Nguyen T, Cheng R, Kennedy JL, George SR, O’Dowd BF (2003) Discovery of a null mutation in a human trace amine receptor gene. Genomics 82:531-536. CrossRef Medline

Vassar R, Ngai J, Axel R (1993) Spatial segregation of odorant receptor expression in the mammalian olfactory epithelium. Cell 74:309-318. CrossRef Medline

Vassar R, Chao SK, Sitcheran R, Nuñez JM, Vosshall LB, Axel R (1994) Topographic organization of sensory projections to the olfactory bulb. Cell 79:981-991. CrossRef Medline

Wallrabenstein I, Kuklan J, Weber L, Zborala S, Werner M, Altmüller J, Becker C, Schmidt A, Hatt H, Hummel T, Gisselmann G (2013) Human trace amine-associated receptor TAAR5 can be activated by trimethylamine. PLoS One 8:e54950. CrossRef Medline

Yoshihara Y, Kawasaki M, Tamada A, Fujita H, Hayashi H, Kagamiyama H, Mori K (1997) OCAM: a new member of the neural cell adhesion molecule family related to zone-to-zone projection of olfactory and vomeronasal axons. J Neurosci 17:5830-5842. Medline

Zhang X, Firestein S (2002) The olfactory receptor gene superfamily of the mouse. Nat Neurosci 5:124-133. CrossRef Medline

Zhang J, Pacifico R, Cawley D, Feinstein P, Bozza T (2013) Ultrasensitive detection of amines by a trace amine-associated receptor. J Neurosci 33: 3228-3239. CrossRef Medline

Zhang X, De la Cruz O, Pinto JM, Nicolae D, Firestein S, Gilad Y (2007) Characterizing the expression of the human olfactory receptor gene family using a novel DNA microarray. Genome Biol 8:R86. CrossRef Medline

Zheng C, Feinstein P, Bozza T, Rodriguez I, Mombaerts P (2000) Peripheral olfactory projections are differentially affected in mice deficient in a cyclic nucleotide-gated channel subunit. Neuron 26:81-91. CrossRef Medline 